\title{
PENGARUH FILM KEKERASAN TERHADAP AGRESIVITAS SUATU STUDI META-ANALISIS
}

Tina Afiatin

\begin{abstract}
Abstrak
Penelitian ini merupakan studi meta analisis tentang pengaruh film kekerasan terhadap agresivitas. Data penelitian terdiri dari 20 penelitian. Ada 9 penelitian memiliki variabel dependen dan variabel independen yang sama, sedangkan 11 penelitian yang lain adalah penelitian tentang agresivitas dan hubungannya dengan variabel independen yang lain. Analisis data adalah berdasarkan 9 penelitian tersebut.

Hasil analisis data menunjukkan bahwa korelasi aktual (populasi) antara variabel film kekerasan dan agresivitas selalu positif, artinya makin intens film kekerasan maka makin meningkat pula agresivitas. Data penelitian ini heterogen, sehingga pada data ini terdapat primary second order sampling error. Keadaan demikian memprediksikan adanya variabel moderator potensial, oleh karena itu perlu diteliti melalui prediksi teoritis misalnya : jenis kelamin, usia dan tingkat pendidikan atau melalui unsuspected moderator yang dideteksi melalui varians residual.
\end{abstract}

Kata kunci : film kekerasan, agresivitas, meta analisis

\section{PENGANTAR}

Akhir-akhir ini berkembang polemik mengenai pengaruh film kekerasan terhadap agresivitas. Beberapa ahli mendukung pendapat bahwa film kekerasan dapat meningkatkan perilaku agresif, sementara ahli-ahli lain menolak pendapat tersebut. Beberapa penelitian dilakukan untuk mendapatkan bukti empiris tentang masalah tersebut, namun hasil yang diperoleh tidak selalu selaras. Ada yang menunjukkan bahwa memang film kekerasan dapat meningkatkan perilaku egresif tetapi penelitian lain membuktikan bahwa tidak ada hubungan positif yang signifikan antara film kekerasan dan agresivitas. Metode tertentu diperlukan untuk mengintegrasikan hasil temuan penelitian sehingga dapat memberikan gambaran dan penjelasan yang komprehensif tentang topik tersebut. Dalam ilmu sosial memungkinkan adanya pengkajian suatu topik yang ditinjau dari berbagai segi atau bermacam-macam pendekatan.

Banyaknya upaya untuk melakukan verifikasi atau replikasi secara empirik mengenai suatu topik memungkinkan dilakukannya pengkajian mengenai keajegan atau ketidak ajegan penelitian (Soetjipto, 1995). Semakin banyak studi yang dilakukan sering justru memperbesar terjadinya variasi 
hasil atau kesimpulan penelitian. Hal ini merupakan upaya positif dalam pengintegrasian hasil-hasil penelitian sebagai usaha mengatasi kelemahan penelitian tunggal (single study). Menurut Cook, dkk (1992) penelitian tunggal tidak hanya gagal untuk menghasilkan pengetahuan dengan generalisasi yang luas, tetapi juga gagal untuk menghasilkan pengetahuan dengan penjelasan yang komprehensif.

Upaya untuk merangkum dan menyimpulkan berbagai hasil penelitian telah banyak dilakukan. Pada saat ini meta-analisis merupakan cara yang paling terkenal (Hedges dan Olkin, 1985). Meta-analisis merupakan suatu teknik kuantitatif yang bertujuan untuk mensintsakan hasil beberapa penelitian, termasuk survei opini, studi korelasional, studi eksperimental dan kuasi eksperimental serta model-model analisis regresi (Cook, dkk, 1992).

Prosedur dalam melakukan meta-analisis dijelaskan oleh Cook, dkk (1992) dengan melalui lima fase yang disebut sebagai proses penelitian dalam meta-analisis. Kelima fase tersebut adalah:

1. Formulasi masalah (problem formulation)

2. Pengumpulan data (data collection)

3. Pencarian kembali dan evakuasi data (data retrieval and evaluation)

4. Analisis dan interpretasi (analysis and interpretation)

5. Presentasi umum (public presentation)

Artikel ini akan mengkaji suatu topik yang akhir-akhir ini menarik perhatian yaitu tentang hubungan antara film kekerasan dan egresivitas. Banyak penelitian yang bertujuan untuk mengetahui hubungan atau pengaruh film kekerasan dengan agresivitas. Teori yang mendasari hubungan film kekerasan dengan agresivitas adalah film kekerasan menambah belajar lebih agresif (efek modeling). Artinya, agresi orang lain diamati dan diangkat sebagai perilaku sendiri (Bandura, 1977; Byrne dan Kathryn, 1981).

Beberapa penelitian yang meneliti hubungan kedua variabel tersebut menghasilkan korelasi yang berbeda-beda. Hal ini menimbulkan pertanyaan tentang korelasi yang sesungguhnya (pada tingkat populasi) antara variabel film kekerasan dan agresivitas. Meta-analisis dilakukan untuk mengetahui korelasi pada tingkat populasi antara dua varianel tersebut. Meta-analisis menyediakan prosedur pengintegrasian berbagai temuan studi secara kuantitatif dan sistematik (Hunter dan Schmidt, 1990).

Melalui prosedur meta-analisis berbagai temuan dari berbagai studi yang pernah dilakukan dapat diintegrasikan dan kemudian dibangun suatu pengetahuan yang lebih komprehensif. Berbagai temuan studi yang semula kelihatannya saling bertentangan dan sulit diakumulasikan menjadi bermakna dan pengetahuan kumulatif dapat disusun dengan melalui prosedur meta analisis. Kesimpulan umum dapat ditarik dari berbagai studi yang pernah dilakukan. Meta-analisis memberikan bukti bahwa comulativeness temuan-temuan penelitian dalam ilmu-ilmu perilaku dapat dilakukan sebagaimana dalam ilmu-ilmu fisik. 
Beberapa teknik meta-analisis dikemukakan oleh Hunter dan Schmidt (1990), yaitu metode naratif, metode tes signifikansi, metode Glassian dan metode psikometrik. Metode psikometrik merupakan metode yang menggabungkan hasil penelitian dengan ratarata dan mencari varians hasil penelitian dengan mempertimbangkan 11 artifak (ketidaksempurnaan, kesalahan) penelitian.

Menurut Hunter dan Schmidt (1990) ada 11 artifak yang dapat mengubah besarnya korelasi hasil penelitian dalam perbandingan terhadap korelasi aktual. Artifak-artifak tersebut adalah :

1. Kesalahan sampel (sampling error)

2. Kesalahan pengukuran pada variabel dependen

3. Kesalahan pengukuran pada variabel independen

4. Dikotomisasi variabel dependen yang kontinu

5. Dikotomisasi variabel independen yang kontinu

6. Variasi rentangan variabel independen

7. Artifak atrisi

8. Ketidaksempurnaan validitas konstruk variabel dependen

9. Ketidaksempurnaan validitas konstruk variabel independen

10. Kesalahan teknis pelaporan karena ketidaktelitian manusia

11. Varian yang disebabkan kesalahan faktor luar

Artikel ini akan menerapkan penggunaan meta-analisis psikometris untuk mengetahui hubungan film kekerasan dengan agresivitas. Prosedur yang akan digunakan mengikuti tahapan yang dikemukakan oleh Cook, dkk (1992).

\section{FORMULASI MASALAH}

Penelitian ini mengungkap tentang variabel dependen agresivitas dan variabel independen film kekerasan. Agresivitas adalah perilaku (perbuatan, perkataan atau sikap) yang mengandung unsur-unsur kemarahan, kebencian dan penyerangan dengan maksud melukai (secara fisik maupun psikis) orang atau makhluk hidup atau mengakibatkan kerusakan fisik terhadap objek dalam bentuk agresi fisik, agresi verbal, kemarahan dan kebencian.

Film kekerasan adalah film-film yang mengandung unsur tayangan kekerasan yang menampilkan ciri-ciri agresi fisik, agresi verbal, keberhasilan melalui usaha kekerasan, dan memperlihatkan luka, darah serta pengrusakan.

\section{PENGUMPULAN DATA}

Prosedur pengumpulan data dilakukan dengan mereview hasil-hasil penelitian yang terdapat di dalam jurnal, tesis, skripsi dan laporan penelitian yang ada di Perpustakaan Fakultas Psikologi UGM. Data yang dikumpulkan adalah hasil-hasil penelitian tentang hubungan antara film kekerasan dengan agresivitas. Selain itu juga dikumpulkan data tentang variabel dependen yaitu agresivitas. Hal ini dimaksudkan untuk mendapatkan informasi tambahan mengenai pengukuran variabel dependen.

Data yang diperoleh adalah : sembilan penelitian tentang hubungan antara film kekerasan dengan agresivitas; dan 11 penelitian tentang 
variabel dependen agresivitas dengan berbagai variabel independen (jenis kelamin, usia, humor seksual, jenis film erotic-neutral, jenis kawasan, pola asuh orang tua, pemenuhan kebutuhan psikologis, religiusitas, tingkatan dalam latihan pernafasan dan konseling kelompok).

Berikut ini akan dikemukakan data deskriptif dari 20 penelitian yang akan digunakan dalam meta-analisis tentang hubungan film kekerasan dan agresivitas. Data yang disajikan dimaksudkan untuk memberikan gambaran tentang penelitian-penelitian yang pemah dilakukan terhadap topik tersebut. Hal ini dapat merupakan prosedur untuk menemukan variabel moderator potensial, namun tentu saja tidak lepas dari keterbatasan dan kendala yang ditemui, yaitu minimnya informasi yang diperoleh dari sumber-sumber yang ada.

\section{Sumber Data Penelitian}

$\mathrm{N}$

Persentase

1. Jurnal

2. Tesis

\section{4}

\section{2}

3. Skripsi

3

4. Lap.Penelitian

$$
\text { Jumlah } \quad \overline{20} \quad-100 \%
$$

\section{A. Tahun Penelitian/Publikasi}

$\mathrm{N}$

Persentase

1. $1971-1980$

\begin{tabular}{lr}
3 & $15 \%$ \\
8 & $40 \%$ \\
9 & $45 \%$ \\
\hline 20 & $100 \%$
\end{tabular}

B. Negara Tempat Penelitian

$\mathrm{N}$

Persentase

1. Indonesia $\quad 10 \quad 50 \%$

2. Amerika $8 \quad 40 \%$

3. Tidak disebutkan $2 \quad .10 \%$ Jumlah $\quad 20 \quad 100 \%$

C. Pendidikan Subjek Penelitian N

Persentase

1. Prasekolah

2. $S D$

3. SMP

4. SMA $4 \quad 20 \%$

5. Perguruan $\begin{array}{lll}\text { Tinggi } & 5 & 25 \%\end{array}$

6. Tidak $\begin{array}{lll}\text { disebutkan } & \frac{3}{20} & \frac{15 \%}{100 \%}\end{array}$

D. Pengukuran Variabel Agresivitas $\mathrm{N}$

Persentase

1. Skala Agresivitas $525 \%$

2. Angket/ Kuesioner $\quad 9 \quad 45 \%$

3. Rating Observasi Perilaku Agresif $\quad 4 \quad 20 \%$

4. SelfReport $1 \quad 5 \%$

5. Tidak disebutkan $1 \quad 5 \%$ Jumlah $\quad \overline{20} \quad \frac{}{100 \%}$ 


\section{E. Pengukuran Variabel Film Kekerasan}

Persentase

1. Skala Minat

Terhadap Film

Kekerasan

2. Angket Film yang ditonton

3. Rating Film

4. Tidak disebutkan Jumlah

Dari 20 penelitian yang berhasil dikumpulkan ternyata ada 9 (sembilan) penelitian yang meneliti variabel yang sama yaitu hubungan film kekerasan dan agresivitas. Sedangkan 11 penelitian yang lain adalah penelitian tentang agresivitas dan hubungannya dengan variabel independen yang lain.

\section{EVALUASI DATA}

Menurut Cook, dkk (1992) evaluasi data dalam meta-analisis (terhadap hasil penelitian) meliputi penelitian kualitas data individual (masing-masing penelitian). Dalam review penelitian, peneliti membuat suatu set penilaian tentang validitas penelitian dan hasil-hasilnya. Penilaian sering juga termasuk pengukuran

1. Signifikansi

positif $1 \% \quad 22 \quad 51,16 \%$

2. Signifikansi positif $5 \%$

$\mathrm{N}$

3. Signifikansi negatif

4. Tidak signifikansi

$6,98 \%$

5. Tidak disebutkan

6

$13,95 \%$

Jumlah $\quad \frac{1}{20} \quad \frac{2,33 \%}{100 \%}$

Pada hasil penelitian diperoleh data lebih dari 20 , yaitu 43 . Hal ini disebabkan dalam beberapa penelitian diperoleh hasil tidak hanya satu, tetapi beberapa korelasi ( $r$ ) atau nilai perbedaan (d), sehingga hasilnya menjadi lebih banyak. Temuan yang demikian menurut Hunter dan Schmidt (1990) merupakan replikasi, baik bersifat replikasi penuh, replikasi konseptual dan analisis sub-kelompok. variabel, alat ukurnya, dan ketepatan analisis statistik. Penentuan kriteria harus dikemukakan secara jelas dalam aplikasinya.

Mengingat keterbatasan penulis dalam penelitian ini evaluasi tidak dilakukan pada masing-masing penelitian, tetapi dikelompokkan pada jenisjenis penelitiannya. Dari sembilan penelitian dengan variabel dependen dan independen yang sama diperoleh hasil penelitian studi korelasi ada lima, sedangkan penelitian studi perbedaan ada empat.

Berdasarkan hasil temuan tersebut maka untuk penelitian tentang studi perbedaan (menghasilkan $\mathrm{t}$ dan F) perlu dikonversikan ke dalam nilai r. Menurut Hunter dan Schmidt (1990) rumus untuk mengkonversi nilai d (dari $t$ dan F) ke nilai $r$ adalah:

$$
d=2 r \text { atau } r=d / 2
$$


Sementara konversi nilai F ke t adalah:

$$
F=t^{2} \text { atau } t=\sqrt{F}
$$

Dan rumus $r$ dari nilai $t$ adalah :

$$
r=t / \sqrt{t^{2}+N-2}
$$

Dengan demikian untuk memperoleh hasil meta-analisis studi korelasional ( $r$ ) maka untuk penelitian yang menghasilkan nilai $t$ atau F perlu dilakukan konversi terlebih dahulu. Berdasarkan hasil temuan artifak maka dapat dinyatakan bahwa informasi mengenai beberapa artifak hanya tersedia secara random pada sebagian studi, sehingga tidak memungkinkan dilakukan koreksi terhadap masing-masing studi secaraindividual. Dengan demikian maka meta-analisis dilakukan dengan mengoreksi artifak yang informasinya tersedia secara random (artifak yang sporadis). Dari sembilan penelitian hanya informasi mengenai kesalahan sampling yang tersedia pada semua studi.

\section{ANALISIS DATA DAN INTERPRETASI}

Sebelum dilakukan analisis dan interpretasi data, terlebih terlebih dahulu akan disajikan informasi sumber artifak yang dapat dikoreksi dari sembilan penelitian. Data tersebut terdapat dalam tabel 1

Tabel 1

Data Informasi Sumber Artifak dari Sembilan Penelitian

\begin{tabular}{|l|c|c|c|c|c|l|}
\hline No & $\mathbf{r}_{\mathbf{x x}}$ & $\mathbf{a}$ & $\mathbf{r}_{\mathbf{y y}}$ & $\mathbf{b}$ & $\mathbf{N}$ & \multicolumn{1}{|c|}{$\mathbf{R}_{\mathbf{x y}} / \mathbf{d}$} \\
\hline 1. & 0,916 & 0,957 & 0,890 & 0,943 & 430 & $\mathrm{r}=0,263$ \\
\hline 2. & 0,727 & 0,853 & 0,822 & 0,906 & 237 & $\mathrm{r}=0,392$ \\
\hline 3. & - & - & - & - & 86 & $\mathrm{t}=1,302$ \\
\hline 4. & 0,87 & 0,933 & - & - & 100 & $\mathrm{~F}=248,55$ \\
\hline 5. & - & - & 0,97 & 0,985 & 169 & $\mathrm{~F}=2,27$ \\
\hline 6. & - & - & 0,50 & 0,707 & 169 & $\mathrm{~F}=12,84$ \\
\hline 7. & - & - & - & - & 600 & $\mathrm{r}=0,41$ \\
\hline 8. & 0,83 & 0,911 & - & - & 60 & $\mathrm{r}=0,49$ \\
\hline 9. & 0,916 & 0,957 & 0,891 & 0,944 & 430 & $\mathrm{r}=0,263$ \\
\hline
\end{tabular}

Keterangan :

$r_{x x}=$ reliabilitas alat ukur variabel Film Kekerasan

$$
\begin{aligned}
a= & \sqrt{r_{x x}} \\
r_{y y}= & \text { reliabilitas alat ukur variabel } \\
& \text { agresivitas }
\end{aligned}
$$

$$
\begin{aligned}
\mathrm{b}= & \sqrt{r_{y y}} \\
\mathrm{~N}= & \text { jumlah sampel penelitian } \\
\mathrm{r}_{\mathrm{yy}}= & \text { korelasi variabel Film } \\
& \begin{array}{l}
\text { Kekerasan dengan agresi- } \\
\text { vitas }
\end{array} \\
\mathrm{d}= & \text { nilai perbedaan agresivitas } \\
& \text { berdasar Film Kekerasan }
\end{aligned}
$$


Berdasar Tabel 1 tersebut maka perlu dilakukan konversi hasil nilai d pada penelitian nomor $3,4,5$ dan 6 ke dalam nilai r. Konversi hasil penelitian sebagai berikut :

1. Penelitian nomor 3

$$
\begin{aligned}
\text { Diperoleh } t & =1,302 \text { maka } r: \\
r & =t / t^{2}+\mathrm{N}-2 \\
& =1,302 / \sqrt{(1,302)^{2}+(86-2)} \\
& =1,302 / \sqrt{1,695+84} \\
& =1,302 / \sqrt{9,257} \\
& =0,141
\end{aligned}
$$

2. Penelitian nomor 4

$$
\begin{aligned}
\text { Diperoleh } F & =248,55 \text { maka } t=\sqrt{F}=15,765 \\
r & =15,765 / \sqrt{(15,765)^{2}+(100-2)} \\
& =15,765 / \sqrt{248,54+98} \\
& =15,765 / \sqrt{18,616} \\
& =0,846
\end{aligned}
$$

3. Penelitian nomor 5

$$
\begin{aligned}
\text { Diperoleh } F & =2,27 \text { maka } t=\sqrt{F}=1,507 \\
r & =1,507 / \sqrt{(1,507)^{2}+(169-2)} \\
& =1,507 / \sqrt{2,271+167} \\
& =1,507 / \sqrt{13,010} \\
& =0,116
\end{aligned}
$$

4. Penelitian nomor 6

$$
\begin{aligned}
\text { Diperoleh } F & =12,84 \text { maka } \mathrm{t}=\sqrt{\mathrm{F}}=3,583 \\
r & =3,583 / \sqrt{(3,583)^{2}+(169-2)} \\
& =3,583 / \sqrt{12,838+167} \\
& =3,583 / \sqrt{13,410} \\
& =0,267
\end{aligned}
$$


Berdasar hasil perhitungan konversi nilai $\mathrm{d}$ ke dalam nilai $\mathrm{r}$ maka data penelitian dengan semua nilai r seperti terdapat pada Tabel 2.

Tabel 2

Data informasi Sumber Artifak dari Sembilan Penelitian yang telah Dikonversi

\begin{tabular}{|l|r|c|c|c|c|}
\hline \multicolumn{1}{|c|}{$\mathrm{R}$} & $\mathrm{N}-1$ & $(\mathrm{r}-\mathrm{r})$ & $(\mathrm{r}-\mathrm{r})$ & $(\mathrm{N}-1)\left(\mathrm{r}-\mathrm{r}^{2}\right.$ & $\frac{(\mathrm{N}-1)(\mathrm{r}-\mathrm{r})^{2}}{(1-\mathrm{r})}$ \\
\hline 0,263 & 429 & $-0,068$ & $4,624^{-03}$ & 1,984 & 1,315 \\
0,392 & 236 & 0,061 & $3,721^{-03}$ & 0,878 & 1,312 \\
0,141 & 85 & $-0,19$ & 0,0361 & 3,069 & 4,587 \\
0,846 & 99 & 0,515 & 0,2652 & 26,255 & 39,245 \\
0,116 & 168 & $-0,215$ & 0,0462 & 7,762 & 11,602 \\
0,267 & 168 & $-0,064$ & $4,096^{-03}$ & 0,687 & 1,027 \\
0,41 & 599 & 0,079 & $6,241^{-03}$ & 3,738 & 5,587 \\
0,49 & 59 & 0,159 & 0,0253 & 1,493 & 2,232 \\
0,263 & 429 & $-0,068$ & $4,624^{-03}$ & 1,984 & 2,965 \\
\hline & & & & $\chi^{2}$ & 69,872 \\
& & & & $\mathrm{db}$ & 8 \\
& & & & $\mathrm{p}$ & $<0,05$ \\
\hline
\end{tabular}

Berdasarkan data pada tabel 2 selanjutnya dilakukan analisis untuk mendapatkan : (a) rata-rata $r$, (b) rata-rata sampel $(\mathrm{N})$, (c) varians rata-rata, (d) koreksi kesalahan sampling, serta (e) koreksi pengukuran dari uji perbedaan angka korelasi.

\section{A. Rata-rata $\mathbf{r}(\mathbf{r})$}

$$
\begin{aligned}
& \bar{r}=\frac{\sum\left(N_{i} r_{i}\right)}{\Sigma N_{i}} \\
& =[(430 \times 0,263)+(237 \times 0,392)+(86 \times 0,141)+(100 \times 0,846)+(169 \times \\
& 0,116)+(169 \times 0,267)+(600 \times 0,41)+(60 \times 0,49)+(430 \times 0,263)] / 2281 \\
& 113,09+92,904+12,126+84,6+19,604+45,123+246+29,4+113,09 \\
& =
\end{aligned}
$$

$$
=\frac{755,937}{2281}=0,331
$$

\section{B. Rata-rata Sampel (N)}

$$
\bar{N}=\frac{\Sigma\left(N_{i}\right)}{K}
$$




$$
=\frac{2281}{9}=253,44
$$

\section{Rata-rata Varians $\left(\mathrm{S}_{\mathrm{r}}^{2}\right)$}

$$
\begin{aligned}
& \Sigma\left[N_{i}\left(r_{i}-r\right)^{2}\right. \\
& S_{r}^{2}=\frac{N_{i}}{\Sigma N_{i}} \\
& =\left[\left(430(0,263-0,331)^{2}+237(0,392-0,331)^{2}+86(0,141-0,331)^{2}\right.\right. \\
& +100(0,846-0,331)^{2}+169(0,116-0,331)^{2}+169(0.267- \\
& 0,331)^{2}+600(0,41-0,331)^{2}+60(0,49-0,331)^{2}+430(0,263- \\
& 0,331)^{2} / 2281 \\
& =\frac{1,988+66,938+2,704+73,644+7,812+0,692+3,745+1,517+1,988}{2281} \\
& =\frac{161,028}{2281}=0,0706
\end{aligned}
$$

\section{Koreksi Kesalahan Sampling}

$$
\begin{aligned}
& S_{e}^{2}=\frac{\left(1-r^{2}\right)^{2}}{(N-1)}=\frac{\left(1-0,331^{2}\right)^{2}}{(253,44-1)}=\frac{0,7929}{252,44}=3,1409^{-03} \\
& S^{2} x y=S_{r}^{2}-S_{e}^{2}=0,0706-3,1409^{-03}=0,0675 \\
& S D_{x y}=\sqrt{S^{2}} x y=\sqrt{0,0675}=0,2598 \\
& \text { Interval kepercayaan } 95 \%=r-1,96\left(S_{x y}\right) \leq \rho_{x y} \leq r+1,96\left(S_{x y}\right) \\
& \quad=0,331-1,96(0,2598) \leq \rho_{x y} \leq 0,331+1,96(0,2598) \\
& =-0,1782 \leq \rho_{x y} \leq 0,8402
\end{aligned}
$$


E. Koreksi Artifak Reliabilitas Variabel Bebas dan Variabel Tergantung

$$
\begin{aligned}
& \bar{A}=\text { Ave (a) Eve (b) } \Rightarrow 0,992 \times 0,897=0,827 \\
& \bar{\rho}_{\mathrm{xy}}=\overline{\mathrm{r}} / \overline{\mathrm{A}}=0,331 / 0,827=0,4002 \\
& V=\frac{S D^{2} a}{A v e^{2} a}+\frac{S D^{2} b}{A v e^{2} b} \Rightarrow \frac{(0,0386)^{2}}{(0,922)^{2}}+\frac{(0,0982)^{2}}{(0,897)^{2}} \\
& =2,6115^{-06}+1,1564^{-04}=0,0124 \\
& S^{2} x y=\frac{S^{2} x y-r \cdot A^{2} \cdot V}{A^{2}} \\
& =\frac{0,0675-0,4002 \times 0,827^{2} \times 0,0124}{0,827^{2}} \\
& =\frac{0,0675-0.0394}{0,6839}=\frac{0,0281}{0,6839}=0,0411 \\
& S D_{x y}=\sqrt{0,0411}=0,2027
\end{aligned}
$$

Interval kepercayaan 95\% :

$$
\begin{gathered}
0,4002-1,96(0,2027) \leq \rho_{x y} \leq 0,4002+1,96(0,2027) \\
0,0129 \leq \rho_{x y} \leq 0,7975
\end{gathered}
$$

\section{F. Pengetesan Homogenitas}

$$
\begin{aligned}
Q & =\frac{K \cdot \operatorname{Var}()}{\operatorname{Var} e}=\frac{9 \times 0,0411}{3,1409^{-03}}=\frac{0,3699}{3,1409^{-03}} \\
& =117,77
\end{aligned}
$$

$\chi^{2}$ dengan $\mathrm{db} 8=15,507$ 
$Q=117,77>15,507 \rightarrow$ heterogen

\section{G. Pengujian Perbedaan Angka Korelasi}

Rumus yang digunakan :

$$
\chi^{2} \mathrm{~K}-1=\Sigma_{i} \frac{\left(\mathrm{N}_{\mathrm{i}}-1\right)\left(\mathrm{r}_{\mathrm{i}}-\mathrm{r}\right)^{2}}{(1-\mathrm{r})}
$$

Diperoleh $\chi^{2}=69,872$

$\chi^{2} \mathrm{tdb} 8=15,507 \quad \chi_{0}^{2}>\chi_{1}^{2} \rightarrow$ Ho diterima

Perhitungan selengkapnya terdapat dalam Tabel 3.

Tabel 3

Perhitunan $\mathrm{c}^{2}$ Perbedaan Koefisien Korelasi

\begin{tabular}{|c|c|c|c|c|c|c|}
\hline No. & $\mathbf{r}_{\mathbf{x x}}$ & $\mathbf{a}$ & $\mathbf{r}_{\mathbf{y}}$ & $\mathbf{b}$ & $\mathbf{N}$ & $\mathbf{R}_{\mathbf{x y}} / \mathbf{d}$ \\
\hline 1 & 0,916 & 0,957 & 0,890 & 0,943 & 430 & $\mathrm{r}=0,263$ \\
\hline 2 & 0,727 & 0,853 & 0,822 & 0,906 & 237 & $\mathrm{r}=0,392$ \\
\hline 3 & - & - & - & - & 86 & $\mathrm{r}=1,302$ \\
\hline 4 & 0,87 & 0,933 & - & - & 100 & $\mathrm{~F}=248,55$ \\
\hline 5 & - & - & 0,97 & 0,985 & 169 & $\mathrm{~F}=2,27$ \\
\hline 6 & - & - & 0,50 & 0,707 & 169 & $\mathrm{~F}=12,84$ \\
\hline 7 & - & - & - & - & 600 & $\mathrm{r}=0,41$ \\
\hline 8 & 0,83 & 0,911 & - & - & 60 & $\mathrm{r}=0,49$ \\
\hline 9 & 0,916 & 0,957 & 0,891 & 0,944 & 430 & $\mathrm{r}=0,263$ \\
\hline
\end{tabular}

Jadi ada perbedaan sampel dari 9 penelitian. Hal ini berarti bahwa perbedaan koefisien korelasi disebabkan karena adanya perbedaan sampel.

Setelah melalui pengoreksian artifak kesalahan sampling dan pengoreksian artifak reliabilitas variabel dependen dan independen diperoleh hasil :

Rata-rata $\rho=0,4002$

$\operatorname{SD} \rho \quad=0,2027$

Interval kepercayaan $95 \%$

$0,4002-1,96(0,2027) \leq \rho_{x y} \leq 0,4002+1,96(0,2027)$

$0,0029 \leq \rho_{x y} \leq 0,7975$ 
Hasil ini menunjukkan bahwa varians rho setelah dikoreksi kesalahan sampling reliabilitas alat ukur variabel dependen dan independen masih besar. Besarnya varians rho dapat disebabkan karena adanya artifak lain yang tidak terkoreksi (misalnya dikotomisasi variabel dependen dan independen, variasi rentangan itu adalah independen dan sebagainya). Hal ini disebabkan karena tidak adanya informasi atau juga karena adanya second order sampling error (kesalahan estimasi mean dan SD dalam meta-analisis karena kecilnya jumlah sampel penelitian yang digunakan dalam meta-analisis).

Menurut Hunter dan Schmidt (1990) ada dua macam second order sampling error (SOSE) yaitu :

1. Secondary SOSE, yaitu SOSE yang disebabkan karena tidak lengkapnya artifak sampling error dalam penelitian yang digunakan dalam meta-analisis.

2. Primary SOSE, yaitu SOSE yang disebabkan karena bervariasinya hasil penelitian yang digunakan dalam meta-analisis.

Pada Primary SOSE ada dua kemungkinan :

1. Kasus homogenitas, yaitu bila hasil penelitian sebenarnya (populasi) tidak berbeda dengan hasil penelitian meta-analisis.

2. Kasus heterogenitas, yaitu hasil penelitian populasi berbeda-beda.

Dalam penelitian ini berdasarkan perhitungan yang telah dikemukakan diperoleh kesimpulan uji homogenitas, bahwa hasil penelitian ini merupakan kasus heterogenitas. Jadi dalam data meta-analisis terdapat dua SOSE, yaitu primary dan secondary SOSE.
Menurut Hunter dan Schmidt kalau terjadi hal yang demikian maka perlu diselesaikan dulu penyelesaian primary SOSE lebih dulu, yaitu dengan mendeteksi adanya variabel moderator potensial. Ada dua cara untuk mendeteksi variabel moderator, yaitu melalui prediksi teoritis dan menggunakan unsuspected moderator.

Prediksi teoritis menggunakan binary moderator variabel yaitu dengan memisahkan $\mathrm{K}$ studi meta-analisis overall ke dalam subset dengan $\mathrm{K}_{1}$ dan $\mathrm{K}_{\mathrm{A}}$ dalam tiap-tiap studi (dimana $\mathrm{K}_{1}+$ $K_{A}=K$ ). Misalnya dalam penelitian ini tingkat pendidikan subjek dibedakan $\mathrm{K}_{1}$ $=$ Prasekolah, $\mathrm{K}_{2}=\mathrm{SD}, \mathrm{K}_{3}=\mathrm{SMP}, \mathrm{K}_{4}$ $=\mathrm{SMA}, \mathrm{K}_{5}=\mathrm{PT}$. Apabila effect size kelima mean berbeda dalam prediksi, ini memperkuat adanya variabel tingkat pendidikan sebagai variabel moderator.

Metode unsuspected moderator dilakukan bila variabel moderator tidak diantisipasi (secara teoritis belum tahu), maka hal ini dideteksi dalam bentuk varian residual. Deteksi pada moderator dilakukan dengan membuat estimasi varians dan effect size populasi pada face value. Apabila estimasi varian (o) positif, maka asumsinya ada sumber. variasi non artifak pada penelitianpenelitian tersebut.

\section{PRESENTASI UMUM}

Fase terakhir dari prosedur meta-analisis adalah melakukan presentasi umum. Menurut Cook, dkk (1992) hal ini bila dianalogkan dengan penelitian tunggal adalah membuat laporan penelitian. Dalam presentasi umum peneliti dituntut untuk mengikuti suatu format baku. Artinya, bahwa baik 
bentuk dan tipe informasi yang harus dimasukkan harus disamakan.

Kebanyakan laporan ilmiuah mendasarkan pada asumsi bahwa tujuan utama suatu laporan adalah: (1) Membiarkan pembaca menilai prosedur penelitian; (2) Menyediakan informasi yang cukup detil sehingga peneliti lain dapat melakukan replikasi suatu metode studi. Laporan hendaknya memuat beberapa hal, yaitu :

1. Informasi bagaimana literatur dicari.

2. Kriteria apa yang digunakan untuk menilai studi yang relevan.

3. Penggambaran metode penelitian.

4. Karakteristik studi primer yang dijabarkan dalam lembaran coding, dan sebagainya.

\section{KESIMPULAN}

Berdasarkan uraian yang telah dikemukakan maka dapat disimpulkan beberapa hal, yaitu :

1. Penelitian ini merupakan studi meta-analisis tentang pengaruh film kekerasan terhadap agresivitas. Data penelitian terdiri dari 20 penelitian.

Dari 20 penelitian yang meneliti variabel independen dan variabel dependen yang sama ada sembilan penelitian.

Dengan demikian analisis data berdasarkan pada sembilan penelitian tersebut.

2. Dari sembilan penelitian ternyata ada lima penelitian korelasional dan empat penelitian tentang perbedaan, sehingga dilakukan konversi dari nilai d (harga $\mathrm{F}$ dan atau $t)$ ke dalam nilai $F$.
3. Berdasar hasil analisis data diperoleh hasil sebagai berikut:

a. Rata-rata $r=0,331$

b. Rata-rata $\mathrm{N}=253,44$

c. Rata-rata varians $=0,0706$

d. Berdasarkan pengujian perbedaan angka korelasi melalui uji $\chi^{2}$, diperoleh

$\chi^{2}=69,872>\chi_{t}=\quad 15,507$.

Kesimpulannya adalah ada perbedaan sampel dari sembilan penelitian. Hal ini berarti bahwa perbedaan koefisien korelasi disebabkan adanya perbedaan sampel (ada sampling error).

e. Setelah melalui koreksi kesalahan sampling, diperoleh harga rho dengan interval kepercayaan $95 \%$ sebagai berikut :

$-0,1782 \leq \rho_{x y} \leq 0,8402$.

f. Selanjutnya dengan koreksi artifak reliabilitas variabel dependen dan independen diperoleh $=0,4002$ dengan interval kepercayaan $95 \%$ diperoleh rentang nilai sebesar $0,0029 \leq \rho_{x y} \leq$ 0,7975 . Hal ini berarti bahwa harga rho yang telah dikoreksi artifak kesalahan sampel dan reliabilitas variabel dependen dan independen diperoleh harga yang positif (tidak melalui nilai o). Hal ini berarti bahwa korelasi aktual (populasi) antara variabel film kekerasan dan agresivitas adalah selalu positif; artinya 
makin intens film kekerasan maka makin meningkat pula agresivitas. Selain itu juga diketahui bahwa varians rho setelah dikoreksi kesalahan sampling dan reliabilitas alat ukur variabel dependen dan independen masih besar. hal ini disebabkan karena ada artifak lain yang tidak terkoreksi.

g. Hasil akhir uji homogenitas diperoleh harga $Q$ sebesar

$$
\chi^{2}=117,77>\chi^{2}=15,507 .
$$

Kesimpulannya adalah bahwa data penelitian tersebut heterogen.Sehingga dalam data penelitian ini terdapat : primary second order sampling error. Keadaan yang demikian memprediksikan adanya variabel moderator potensial, sehingga perlu diteliti baik melalui prediksi teoritis atau melalui unsus-pected moderator yang dideteksi melalui varians residual.

4. Kesimpulan umum berdasarkan interpretasi hasil analisis data yang telah dikemukakan adalah ada korelasi positif antara film kekerasan dan agresivitas, besarnya korelasi antara dua variabel moderator potensial, misalnya dari tinjauan teoritis adalah jenis kelamin, usia dan tingkat pendidikan.

\section{DAFTAR PUSTAKA}

Bandura, A. 1977. Social Learning Theory: Englewood Cliffs, NJ : Prentice Hall.

Byrne, D. dan Kelly, K. 1981. An Introduction to Personality. Englewood Cliffs, NJ : Prentice Hall.

Cook, T.H; Cooper, H; Cordray, D.S; Hartmann, H; Hedges, L.V; Light, R.J; Leuis, T.A. dan Mosteller, F. 1992. Meta-Analysis For Explanation: A Casebook. New York: Russell Sage Foundation.

Hedges, L.V. dan Oklin, I. 1985. Statistical Method For MetaAnalysis. London : Academic Press, Inc.

Hunter, J.E. dan Schmidt, F.L. 1990. Methods of Meta-Analysis : Correcting Error and Bias in Research Findings. Newburry Park: Sage Publication.

Soetjipto, H.P. 1995. Aplikasi MetaAnalisis Dalam Pengujian Validitas Aitem. Buletin Psikologi, Tahun III, No. 2. 20-28. 